\title{
Pengaruh Pemberian Tepung Daun Kayambang (Salvinia molesta) terhadap Bobot Hidup, Persentase Lemak Abdominal dan Profil Lemak Darah Ayam Broiler
}

\author{
T. Setiawati, U. Atmomarsono dan B. Dwiloka \\ Fakultas Peternakan dan Pertanian, Universitas Diponegoro, \\ Jalan Prof. H. Soedarto, SH, Tembalang 50275 Semarang \\ E-mail: tikasetiasukarnoputri@gmail.com
}

\begin{abstract}
ABSTRAK
Penelitian bertujuan mengetahui pengaruh tepung daun kayambang (Salvinia molesta) sebagai penyusun ransum pakan ayam broiler yang mengandung asam lemak omega 3 , berpengaruh terhadap bobot hidup, persentase lemak abdominal dan profil lemak darah meliputi High Density Lipoprotein (HDL) dan Low Density Lipoprotein (LDL). Materi yang di gunakan adalah 100 ayam broiler unsexied umur 15 hari dengan bobot badan $500 \pm 6,99 \mathrm{~g}$. Ransum perlakuan yaitu T0 (ransum tanpa tepung daun Salvinia molesta); T1 (ransum dengan tepung daun Salvinia molesta 6\%); T2 (ransum dengan tepung daun Salvinia molesta 12\%); dan T3 (ransum dengan penggunaan tepung daun Salvinia molesta 18\%). Hasil penelitian menunjukkan tepung daun Salvinia molesta dalam ransum ayam broiler berpengaruh nyata $(\mathrm{P}<0,05)$ terhadap bobot hidup, perlakuan $\mathrm{T} 1, \mathrm{~T} 2$, T3 menunjukkan penurunan dibandingkan ransum kontrol (T0). Persentase lemak abdominal tidak menunjukan perbedaan yang nyata $(\mathrm{P}<0,05)$. Terjadi peningkatan LDL dari kontrol ke perlakuan. HDL menunjukan perbedaan yang nyata $(\mathrm{P}<0.05)$ dimana $\mathrm{T} 0$ sama dengan $\mathrm{T} 3$, dan $\mathrm{T} 3$ lebih tinggi di bandingkan T1 dan T2, sehingga perlakuan sampai taraf 18\% belum mampu meningkatkan HDL. Dapat disimpulkan bahwa pemberian tepung Salvinia molesta sampai taraf $18 \%$ menurunkan bobot hidup ayam broiler, namun belum mampu menurunkan persentase lemak abdominal, kandungan LDL dan menaikkan kandungan HDL secara signifikan.
\end{abstract}

Kata kunci : Salvinia molesta, ayam broiler, lemak, darah

\section{Influence of Kayambang (Salvinia molesta) leaves flour as a Constituent of Broiler ration on body weight, percentage of abdominal fat and blood lipid profile of broiler chickens}

\section{ABSTRACT}

The study aimed to determine the effect of kayambang leaves flour (Salvinia molesta) as a constituent of broiler ration that contain omega-3 fatty acids, on body weight, percentage of abdominal fat and blood lipid profile including High Density Lipoprotein (HDL) and Low Density Lipropotein $(L D L)$. The material used was 100 broiler chickens unsexied 15 days old with an average a body weight of $500 \pm 6.99 \mathrm{~g}$. Ration treatment consisted of T0 (ration without Salvinia molesta leaf meal); 11 (ration with Salvinia molesta leaf meal 6\%); T2 (ration with Salvinia molesta leaf meal 12 $\%$ ); and T3 (ration with Salvinia molesta leaf meal $18 \%$ ). The results of the study showed Salvinia molesta leaf meal in the ration of broiler chickens affect $(P<0.05)$ body weight. Treatment T1,T2 and T3 showed decreases compared with the control diet (TO). Abdominal fat percentage showed no significant differences $(P<0.05)$. Increase in $L D L$ from control to treatment and decrease $H D L$ were found in this experiment. The conclusion states that the provision of Salvinia molesta flour up to $18 \%$ decreased the live weight of broiler, but did not decrease abdominal fat percentage. The LDL blood was increased and HDL was decreased due to addition of Salvinia molesta flour.

Key words: Salvinia molesta, broiler chicken, fat, blood 


\section{PENDAHULUAN}

Ayam broiler merupakan ayam yang banyak dibudidaya karena pertumbuhannya yang sangat cepat. Keunggulan ayam broiler dapat diandalkan sebagai penyuplai sumber protein hewani yang utama. Pertumbuhan yang cepat pada ayam broiler diikuti pula oleh pertumbuhan lemak dan kolesterol dalam daging. Berbagai upaya dilakukan untuk meningkatkan kualitas produk unggas sehingga nilai jualnya dapat meningkat. Perbaikan pakan dan introduksi suplemen merupakan salah satu cara yang banyak digunakan. Usaha yang dilakukan untuk mengurangi persentase lemak abdominal dan kolesterol darah yaitu dengan memanfaatkan bahan pakan lokal ternak yang mengandung zat aktif yang mampu memengaruhi metabolisme lemak dalam tubuh sehingga menghasilkan lemak esensial dalam daging ayam broiler yang dapat menurunkan persentase lemak abdominal dan kolesterol darah salah satunya dengan pakan yang memiliki zat aktif seperti omega 3. Salvinia molesta (kayambang) adalah tanaman yang mengapung di air. Tanaman ini telah banyak diteliti para ilmuwan untuk mengembangkan potensi dari zat-zat yang terkandung di dalamnya. Daun tanaman ini memiliki kandungan zat aktif omega 3 sebanyak 1,4 \% (Mukherejee, 2010). Kadar lemak pada daun cukup tinggi, dimana cadangan lipid oleh lipase dihidrolisir menjadi gliserol dan asam lemak. Kandungan tepung kayambang sebagai tanaman paku air memiliki protein kasar $16,64 \%$, lemak kasar 6,19\%, serat kasar 9,50\% dan energi $3.900 \mathrm{kkal} / \mathrm{kg}$ (Agung et al., 2007).

Lemak tubuh sebagian besar terdapat dalam jaringan lemak dan lemak di bawah kulit, sekeliling ginjal, sekeliling alat pencernaan dan organ dalam yang lain. Lemak abdominal adalah lemak yang terdapat di sekeliling ampela, usus, otot daerah perut, bursa fabrisius dan kloaka. Lemak abdominal semakin meningkat seiring bertambahnya umur (Anggorodi,
1985). Ayam broiler umur 6 minggu mengandung 3\% lemak abdominal dari total bobot badan. Untuk mengurangi tingginya kandungan kolesterol dan lemak abdomen diupayakan dengan penggunaan pakan yang menghasilkan daging ayam broiler yang aman dan sehat, salah satunya dengan pakan fungsional. Penggunaan kayambang yang mengandung omega-3 dalam pakan akan mempengaruhi metabolisme nutrien terutama lemak, karena adanya asam lemak rantai panjang yang terdapat di dalam kayambang yang dapat menurunkan kadar lemak dan kolesterol darah. Coetzee dan Hoffman (2002) menyatakan bahwa peningkatan level asam lemak omega-3 pada pakan efektif untuk mereduksi asam lemak jenuh pada karkas dan lemak abdominal ayam broiler.

Penelitian Chashnidel (2010) tentang akibat level berbeda pada pemberian omega 3 pada ransum ayam broiler $(0,1,5,3$ dan 4,5\% minyak ikan) mampu menurunkan kandungan triglisirida, LDL, kolesterol, persentase lemak abdominal dan menaikkan kandungan HDL darah. Minyak ikan yang mengandung senyawa aktif omega 3 mampu menurunkan proses lipogenesis di hati dan juga sekresi VLDL sehingga akan mengurangi terjadinya proses katabolisme VLDL yang akan menghasilkan LDL sehingga akan menurunkan kandungan kolesterol dapam darah. Kandungan trigliserida mengalami penurunan dan HDL mengalami kenaikan, hal terjadi karena adanya proses pelepasan muatan ester kolesterol ke dalam hati dilakukan oleh lipase hepatik yang menghidrolisis HDL dan trigliserida untuk menyediakan kolesterol bagi produksi asam empedu dan konsentrasi HDL memiliki kadar bervariasi secara timbal balik dengan konsentrasi trigliserida (Murray et al., 2003). Persentase lemak abdominal menurun seiring dengan menurunnya kandungan trigliserida dalam darah begitu juga sebaliknya, Muchtadi et al. (1993) menyatakan bahwa konsentrasi Trigliserida darah yang tinggi berasal dari tingginya sintesis asam lemak di hati 
Tabel 1. Komposisi dan Kandungan Nutrisi Ransum Perlakuan Periode Starter

\begin{tabular}{|c|c|c|c|c|}
\hline \multirow{2}{*}{ Bahan Pakan } & \multicolumn{4}{|c|}{ Ransum } \\
\hline & T0 & $\mathrm{T} 1$ & $\mathrm{~T} 2$ & T3 \\
\hline \multicolumn{5}{|c|}{ 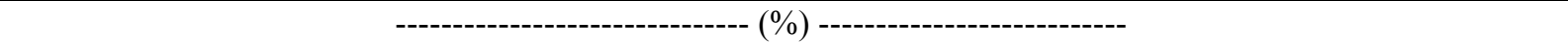 } \\
\hline Jagung & 52,10 & 52,30 & 51,00 & 51,80 \\
\hline Salvinia molesta & 0,00 & 6,00 & 12,00 & 18,00 \\
\hline Bungkil kedelai & 21,30 & 17,00 & 14,00 & 10,80 \\
\hline Minyak & 1,20 & 1,20 & 1,30 & 1,30 \\
\hline Bekatul & 16,80 & 15,90 & 15,10 & 11,80 \\
\hline Tepung Ikan & 5,00 & 5,00 & 5,00 & 5,00 \\
\hline Kapur & 0,80 & 0,70 & 0,40 & 0,40 \\
\hline Premix & 0,80 & 0,70 & 0,40 & 0,30 \\
\hline Metionin & 1,00 & 0,60 & 0,40 & 0,30 \\
\hline Lisin & 1,00 & 0,60 & 0,40 & 0,30 \\
\hline Jumlah & 100,00 & 100,00 & 100,00 & 100,00 \\
\hline \multicolumn{5}{|l|}{ Kandungan Nutrien: } \\
\hline $\begin{array}{l}\text { Energi metabolis } \\
(\mathrm{kkal} / \mathrm{kg})^{* *}\end{array}$ & $2.900,71$ & $2.900,84$ & $2.900,31$ & $2.900,80$ \\
\hline Protein $(\%)^{*}$ & 20,32 & 20,04 & 20,27 & 20,33 \\
\hline Lemak kasar $(\%)^{*}$ & 5,04 & 4,94 & 4,91 & 4,68 \\
\hline Serat kasar $(\%)^{*}$ & 6,76 & 7,37 & 8,02 & 8,11 \\
\hline Kalsium $(\%)^{*}$ & 1,24 & 1,17 & 0,90 & 0,93 \\
\hline Fosfor $(\%) *$ & 0,72 & 0,69 & 0,66 & 0,61 \\
\hline Metionin $(\%) * * *$ & 1,10 & 0,70 & 0,50 & 0,41 \\
\hline Lisin $(\%)^{* * *}$ & 1,39 & 0,98 & 0,78 & 0,66 \\
\hline $\begin{array}{rr}\text { Sumber : } & \text { Hasil } \\
& \mathrm{d} \\
* * & \text { Hasil } \\
& {[\text { Protei }} \\
* * * & \text { Tabel }\end{array}$ & $\begin{array}{l}\text { Proksimat, } \\
\text { ian, Univer } \\
\text { gan energi } \\
\text { 2,25 Lema } \\
\text { si Bahan } \mathrm{Pr}\end{array}$ & $\begin{array}{l}\text { di Labora } \\
\text { negoro }(20 \\
\text { an rumus } \\
\text { BETN] }+2 \\
\text { llah }(2004\end{array}$ & swohardjo & $\begin{array}{l}\text { Fakultas Peternakan } \\
\mathrm{EM}=40,81\{0,87\end{array}$ \\
\hline
\end{tabular}

sehingga terdeposisinya trigliserida darah di dalam jaringan dan lemak. Penelitian ini bertujuan untuk mengetahui adanya pengaruh alternatif bahan pakan lokal penggunaan tepung daun kayambang sebagai bahan penyusun ransum terhadap bobot hidup, persentase lemak abdominal, kadar LDL dan HDL.

\section{MATERI DAN METODE}

Materi yang digunakan dalam penelitian ini yaitu ayam broiler unsexed strain Lohman umur 15 hari sebanyak 100 ekor dengan bobot badan rata-rata $500 \pm$ $6,99 \mathrm{~g}$ dipelihara sampai umur 42 hari dengan menggunakan ransum perlakuan periode starter dan periode finisher. Ransum perlakuan yang digunakan antara lain ransum untuk periode starter $(15-21$ hari) yang mengandung protein kasar (PK) 20\% dan energi metabolis (EM) $2.900 \mathrm{kkal} / \mathrm{kg}$ (Tabel 1) dan ransum untuk periode finisher (22 - 42 hari) yang mengandung PK 19\% dan EM $2.900 \mathrm{kkal} / \mathrm{kg}$ (Tabel 2). Pakan dan air minum diberikan secara ad libitum.

Penelitian ini menggunakan Rancangan Acak Lengkap (RAL) dengan 4 perlakuan dan 5 ulangan sehingga menghasilkan 20 unit percobaan. Pemberian ransum perlakuan antara lain:

T0 : ransum tanpa penggunaan tepung daun kayambang

$\mathrm{T} 1$ : ransum dengan penggunaan tepung daun kayambang $6 \%$

T2 : ransum dengan penggunaan tepung daun kayambang $12 \%$

$\mathrm{T} 3$ : ransum dengan penggunaan tepung daun kayambang $18 \%$

Selama penelitian diberikan vaksin ND La Sota tetes mata dan Vaksin Gumboro melalui tetes mata. Tepung daun Salvinia 
Tabel 2. Komposisi dan Kandungan Nutrisi Ransum Perlakuan Periode Finisher

\begin{tabular}{|c|c|c|c|c|}
\hline \multirow{2}{*}{ Bahan Pakan } & \multicolumn{4}{|c|}{ Ransum } \\
\hline & T0 & $\mathrm{T} 1$ & $\mathrm{~T} 2$ & $\mathrm{~T} 3$ \\
\hline \multicolumn{5}{|c|}{------------------------------- (\%) --------------------------- } \\
\hline Jagung & 54,00 & 52,90 & 52,60 & 52,50 \\
\hline Salvinia molesta & - & 6,00 & 12,00 & 18,00 \\
\hline Bungkil kedelai & 19,30 & 16,50 & 12,70 & 9,40 \\
\hline Minyak & 1,20 & 1,10 & 1,20 & 1,20 \\
\hline Bekatul & 17,70 & 17,60 & 16,40 & 14,60 \\
\hline Tepung Ikan & 4,00 & 3,50 & 3,50 & 3,50 \\
\hline Kapur & 1,00 & 0,70 & 0,40 & 0,20 \\
\hline Premix & 1,00 & 0,50 & 0,40 & 0,20 \\
\hline Metionin & 0,90 & 0,60 & 0,40 & 0,20 \\
\hline Lisin & 0,90 & 0,60 & 0,40 & 0,20 \\
\hline Jumlah & 100,00 & 100,00 & 100,00 & 100,00 \\
\hline \multicolumn{5}{|l|}{ Kandungan Nutrien: } \\
\hline $\begin{array}{l}\text { Energi metabolis } \\
(\mathrm{kkal} / \mathrm{kg})_{* *}\end{array}$ & $2.902,62$ & $2.901,51$ & $2.901,97$ & $2.902,10$ \\
\hline Protein $(\%)^{*}$ & 19,02 & 19,14 & 19,03 & 19,12 \\
\hline Lemak kasar (\%)* & 5,09 & 4,91 & 4,87 & 4,71 \\
\hline Serat kasar $(\%)^{*}$ & 6,86 & 7,66 & 8,20 & 8,63 \\
\hline Kalsium $(\%)^{*}$ & 1,36 & 1,06 & 0,79 & 0,62 \\
\hline Fosfor $(\%)^{*}$ & 0,68 & 0,66 & 0,62 & 0,59 \\
\hline Methionin (\%) & 1,00 & 0,70 & 0,50 & 0,31 \\
\hline Lisin $(\%)$ & 1,28 & 0,99 & 0,78 & 0,57 \\
\hline \multicolumn{5}{|c|}{$\begin{array}{l}\text { Sumber: * Hasil Analisis Proksimat, Ca dan P di Laboratorium Ilmu Nutrisi dan Pakan, Fakultas Peternakan } \\
\text { dan Pertanian, Universitas Diponegoro (2012). } \\
* * \text { Hasil Perhitungan energi berdasarkan rumus Balton (Siswohardjono, 1982) EM }=40,81\{0,87 \\
\text { [Protein kasar + 2,25 Lemak kasar + BETN] }+2,5\} \\
* * * \text { Tabel Komposisi Bahan Pakan Amrullah }(2004)\end{array}$} \\
\hline
\end{tabular}

molesta dibuat dengan memisahkan antara daun dan akar, kemudian daun dikeringkan dan kemudian digiling sehingga menjadi tepung.

Parameter yang diamati meliputi bobot hidup, PERSENTASE lemak abdominal, kadar HDL dan LDL darah. Bobot hidup diambil ketika ternak umur 42 hari dan ditimbang menggunakan timbangan digital. Lemak abdominal didapat dari lemak didalam abdomen termasuk lemak disekeliling ventriculus dan menempel diantara usus, kemudian lemak abdominal ditimbang dan dinyatakan dalam persen dengan cara membagi bobot lemak abdominal dengan bobot hidup dan dikali $100 \%$. Pengukuran kadar HDL, LDL dalam darah ayam broiler dengan melakukan pengambilan sampel darah yang dilakukan pada minggu ke 6 dengan disposable syringes sebanyak $\pm 2 \mathrm{ml}$ melalui vena brachialis. Darah yang telah ditampung dalam tabung EDTA (Ethylene Diamine
Tetra Acid), kemudian diletakkan dalam termos es, disentrifuge $4.000 \mathrm{rpm}$ selama 10 menit kemudian diambil supernatan cairan bening (plasma darah) kemudian dimasukkan dalam tabung eppendorf dan dimasukkan kedalam freezer. Pengukuran kadar HDL, LDL menggunakan metode CHOD-PAP.

Data yang diperoleh kemudian dianalisis menggunakan prosedur analisis ragam (Analysis of Variance / ANOVA) dengan uji $\mathrm{F}$ pada taraf signifikansi $5 \%$, jika hasil analisis menunjukkan pengaruh perlakuan yang nyata kemudian dilanjutkan dengan uji wilayah Ganda Duncan dengan program SPSS versi 16.0.

\section{HASIL DAN PEMBAHASAN}

Hasil penelitian menunjukkan bahwa perlakuan dengan menggunakan tepung daun kayambang dalam ransum ayam broiler berpengaruh nyata $(\mathrm{P}<0,05) \quad$ terhadap 
Tabel 3. Pengaruh pemberian tepung daun kayambang terhadap bobot hidup, Persentase lemak abdominal, LDL dan HDL

\begin{tabular}{lcccc}
\hline \hline Parameter & \multicolumn{4}{c}{ Perlakuan } \\
\cline { 2 - 5 } & $\mathrm{T} 0$ & $\mathrm{~T} 1$ & $\mathrm{~T} 2$ & $\mathrm{~T} 3$ \\
\hline Bobot hidup (g) & $1805,366^{\mathrm{a}}$ & $1681,266^{\mathrm{a}}$ & $1465,034^{\mathrm{b}}$ & $1267,284^{\mathrm{c}}$ \\
Lemak abdominal (\%) & 1,55 & 1,19 & 1,58 & 1,37 \\
LDL (mg/dl) & $29,968^{\mathrm{a}}$ & $17,092^{\mathrm{d}}$ & $27,672^{\mathrm{b}}$ & $23,396^{\mathrm{c}}$ \\
HDL (mg/dl) & $51,352^{\mathrm{a}}$ & $35,406^{\mathrm{c}}$ & $40,00^{\mathrm{b}}$ & $53,508^{\mathrm{a}}$ \\
\hline
\end{tabular}

Keterangan: Superskrip berbeda pada baris yang sama menunjukkan perbedaan yang nyata $(\mathrm{P}<0,05)$

menurunkan bobot hidup, LDL dan HDL, namun tidak berpengaruh nyata terhadap persentase lemak abdominal pada Tabel 3.

Berdasarkan Tabel 3 analisis ragam menunjukkan bahwa tepung kayambang (Salvinia molesta) berpengaruh nyata $(\mathrm{P}<0,05)$ terhadap bobot hidup ayam broiler. Hasil uji nilai tengah bobot badan menunjukkan bahwa T0 (tanpa tepung kayambang) tidak berbeda nyata dengan perlakuan Salvinia molesta 6\%, tetapi lebih tinggi $(\mathrm{P}<0,05)$ di banding tepung kaymabang $12 \% \quad$ (T2) dan tepung kayambang 18 (T3). Hasil uji lebih lanjut menunjukan bahwa bobot hidup level T2 dan T3 nyata $(p<0,05)$ lebih rendah dari pada bobot hidup T1, dan bobot hidup level T3 nyata $(p<0,05)$ lebih rendah di banding level T2. Penurunan bobot hidup dari kontrol (T0) terhadap perlakuaan (T1, T2, T3) dan dimungkinkan karena penggunaan ransum kandungan SK (Serat Kasar) yang tinggi sehingga akan memengaruhi proses pencernaan dan metabolisme dalam tubuh ayam broiler. Dalam ransum percobaan terdapat SK rata - rata $7-8 \%$ dalam pemberiannya (Tabel 1 dan 2). Sesuai dengan pernyataan Amrullah (2004) bahwa ayam broiler mampu mencerna serat kasar sebesar 5-6 \%. Sumiati dan Sumirat (2003) menyatakan bahwa kandungan serat kasar dalam Salvinia molesta merupakan faktor pembatas dalam penggunaan sebagai pakan ternak unggas. Siri et al. (1992) menyatakan bahwa kandungan kadar serat yang tinggi dapat mengurangi ketersediaan energi dan zat makanan lain serta mempengaruhi kecepatan aliran bahan makanan dalam saluran pencernaan pada broiler. Meskipun terjadi penurunan bobot hidup ternak masih di dalam kisaran normal, rata - rata bobot hidup ternak adalah 1.554,738 g. Menurut Zahid dan Hussain (2002) menyatakan bahwa kisaran bobot badan broiler strain Lohman pada minggu 5-6 sekitar 1151,21638,0 gram. Sehingga dalam penambahan tepung kayambang (Salvinia molesta) ini tidak menganggu pertumbuhan ayam broiler.

Analisis persentase lemak abdominal ayam broiler menunjukkan bahwa tepung kayambang (Salvinia molesta) tidak berpengaruh $(\mathrm{P}>0,05)$ terhadap persentase lemak abdominal. Hasil yang tidak berbeda nyata tersebut disebabkan karena dilihat dari konsumsi ransum perhari menujukkan hak yang tidak berbeda nyata yaitu $\mathrm{T} 0=118,07$ $\mathrm{g} / \mathrm{ek} / \mathrm{hr}, \mathrm{T} 1=120,77 \mathrm{~g} / \mathrm{ek} / \mathrm{hr}, \mathrm{T} 2=120,35$ $\mathrm{g} / \mathrm{ek} / \mathrm{hr}, \mathrm{T} 3=118,11 \mathrm{~g} / \mathrm{ek} / \mathrm{hr}$, sehingga menghasilkan pembentukan lemak yang tidak berbeda. Kandungan Lemak kasar ransum yang di tambah dengan tepung kayambang (Salvinia molesta) memilik jumlah yang tidak jauh berbeda untuk setiap perlakuan (Tabel 1 dan 2). Hal ini tidak sesuai dengan penelitian Penelitian Chashnidel (2010) tentang akibat level berbeda pada pemberian omega 3 pada ransum ayam broiler ( $0,1,5,3$ dan 4,5\% minyak ikan) mampu menurunkan kandungan persentase lemak abdominal yang di dukung dengan menurunya kandungan trigliserida pada darah. Pada penelitian tidak terdapat penurunan trigliserida dalam darah, $\mathrm{T} 0=41,79^{\mathrm{c}}, \mathrm{T} 1=$ $54,18^{\mathrm{a}}, \mathrm{T} 2=46,62^{\mathrm{b}}, \mathrm{T} 3=38,97^{\mathrm{c}}$. Lemak pakan berbentuk trigliserida dan asam lemak, kemudian masuk ke dalam tubuh dan melakukan metabolisme. Lemak pakan yang 
berlebihan nantinya akan disimpan di dalam jaringan tubuh dan abdominal. Persentase lemak abdominal menurun seiring dengan menurunnya kandungan trigliserida dalam darah. Lemak abdominal tergantung pada aktifitas sintesis trgiliserida yang dapat dilihat dari kadar darah, Muchtadi et al. (1993) menyatakan bahwa konsentrasi trigliserida darah yang tinggi berasal dari tingginya sintesis asam lemak di hati sehingga mampu meningkatkan kadar lemak jaringan dan lemak abdominal. Santosa dan Tanaka (2001) menyatakan bahwa lemak yang terakumulasi dalam perut dapat dipengaruhi oleh kadar trigliserida di dalam jaringan lemak yang berkaitan dengan konsentrasi trigliserida dalam darah dari sintesis asam lemak di hati. Murray et al. (2003) menerangkan bahwa trigliserida merupakan lemak utama yang disimpan di dalam jaringan tubuh. Tepung kayambang (Salvinia molesta) mengandung zat aktif omega 3 yang merupakan asam lemak tak jenuh rantai panjang yang mudah teroksidasi yang dapat menurunkan proses lipogenesis dan meningkatan pemecahan lemak (lipolisis). Menurut Sardesi (1992), bahwa asam lemak tak jenuh (PUFA) adalah asam lemak yang mudah mengalami oksidasi yang biasanya di timbun di bagian luar (perifer), ketika energi yang di butuhkan kurang maka timbunan lemak abdominal di perifer ini yang akan terlebih dulu di manfaatkan. Hermier (1997) menyatakan bahwa metabolisme lemak abdominal bergantung pada jumlah trigliserida dan tingkat sintesis trigliserida di dalam jaringan adiposa.

Analisis ragam menunjukan bahwa tepung kayambang (Salvinia molesta) berpengaruh nyata $(\mathrm{P}<0,05)$ terhadap kadar LDL ayam broiler. Hasil uji nilai tengah Kadar LDL menunjukkan bahwa T0 (tanpa tepung kayambang) berbeda nyata $(\mathrm{P}<0,05)$ lebih rendah di bandingkan perlakuan level $6 \%, 12 \%$ dan $18 \%$. Kadar LDL perlakuan $6 \%$ berbeda nyata $(\mathrm{P}<0,05)$ lebih tinggi di bandingkan perlakuan level $12 \%$ dan $18 \%$. Uji lebih lanjut bahwa kadar LDL level 12 $\%$ berbeda nyata $(\mathrm{P}<0,05)$ lebih tinggi di bandingkan perlakuan kadar $18 \%$. Terjadi peningkatan jumlah kadar LDL dari konrol ke perlakuan $6 \%$ dan terjadi terjadi penurunan kadar LDL dari level $6 \%$ ke level 12 dan level $18 \%$, namun kontrol memiliki kandungn LDL yang paling rendah.

Peningkatan kadar LDL dari kontrol ke perlakuan. Hal ini selaras dengan meningkatnya kandungan Trigliserida dalam darah dari kontrol ke perlakuan. Meningkatnya kandungan trigliserida dikarenakan oleh terbentuknya kembali kolesterol untuk mensintesis garam empedu yang di manfaatkan untuk mengabsrobsi nutrient khususnya trigliserida yang berada di dalam sel sel tubuh, yang nantinya kan di gunakan sebagai energi ternak. Kelebihan lemak di dalam tubuh akan disimpan dalam bentuk trigliserida, dan akan mengalami perombakan ketika tubuh kekurangan energi untuk metabolisme tubuh, Nort (1984) yang di kutip oleh ketaren (2010) menyatkan bahwa lemak total dalam bentuk trigliserida sebagai cadangan energi untuk aktifitasnya, trigliserida (asam-asam lemak), karbohidrat (glukosa), dan protein (asam-asam amino) yang berasal dari pakan membentuk sel tubuh dan kelebihanya akan disimpan dalam bentuk lemak sebagai cadangan energi.

Peningkatan pada kadar darah trigliserida dari kontrol ke perlakuan mampu meningkatkan pembentukan VLDL (Very Low Density Lipoprotein) yang merupakan induk terbentuknya LDL. Meningkatnya VLDL dalam darah akan diikuti peningkatan pada kadar LDL darah. Santosa dan Tanaka (2001) menyatakan bahwa trigliserida di angkut dalam bentuk kilomikron dan VLDL. Menurut Murray eat al. (2003) Selama katabolisme VLDL terbentuk LDL, sehingga LDL kaya akan kolesterol. LDL berfungsi sebagai transpor kolesterol dalam darah menuju jaringan tubuh melalui endositosis. Kadar LDL yang tinggi menandakan tingginya kadar kolesterol yang tidak baik untuk kesehatan. LDL merupakan lipoprotein yang tergolong lemak jahat karena berikatan dengan kolesterol dan mengangkut menuju jaringan ke sel - sel target. LDL yang berlebihan akan jatuh dan 
mengendap di dinding arteri, dan kemudian lipoprotein HDL akan mengambil kolesterol yang tercecer tersebut untuk di bawa dan di bawa lagi ke dalam hati. Meskipun terjadi penurunan tetapi kadar LDL masih dalam taraf normal, menurut Basmacioglu dan Ergul (2005), menyatakan bahwa kadar kolesterol LDL yang aman bagi kesehatan ternak adalah $\leq 130 \mathrm{mg} / \mathrm{dl}$.

Analisis ragam menunjukan bahwa tepung kayambang (Salvinia molesta) berpengaruh nyata $(\mathrm{P}<0,05)$ terhadap kadar HDL ayam broiler. Hasil uji nilai tengah Kadar HDL (Tabel 3) menunjukkan bahwa T0 (tanpa tepung kayambang) tidak berbeda nyata $(\mathrm{P}<0,05)$ di bandingkan perlakuan pada taraf $18 \%$. Kadar HDL pada perlakuan $6 \%$ berbeda nyata $(\mathrm{P}<0,05)$ lebih redah di bandingkan kontrol, dan perlakuan pada taraf $12 \%$ berbeda nyata $(\mathrm{P}<0,05)$ lebih tinggi di bandingkan taraf $12 \%$ dan lebih rendah dari perlakuan kontrol. Terdapat penurunan kandungan HDL dari kontrol ke dalam perlakuan. Menurunya kandungan HDL dalam darah selaras dengan meningkatnya kandungan LDL dalam darah dari kontrol ke perlakuan dan juga meningkatnya kandungan trigliserida dalam darah. Turunya kandungan HDL dalam darah dipengaruhi oleh naiknya kandungan trigrisireda. Murray et al. (2003) menyatakan bahwa proses pelepasan muatan ester kolesterol ke dalam hati dilakukan oleh lipase hepatik yang menghidrolisis HDL dan trigliserida untuk menyediakan kolesterol bagi produksi asam empedu dan konsentrasi HDL darah memiliki kadar bervariasi dan mempunyai hubungan timbal balik dengan konsentrasi trigliserida darah. Murray et al. (2003) menyatakan penurunan kadar lemak dalam darah dapat di lakukan dengan mempercepat pembuangan lipoprotein dari darah serta menghambat masuknya lipoprotein ke dalam pembuluh darah. Percepatan pembuangan lipoprotein dari darah terjadi dengan bantuan HDL yang dapat mengangkut lipoprotein kembali ke hati. Hasil ini tidak sesuai dengan Murray et al. (2003) yang menyatakan bahwa kandungan senyawa aktif omega 3 yang merupakan asam lemak tak jenuh mampu meningkatkan kadar HDL darah. Senyawa aktif omega 3 mampu merangsang produksi dan sekresi empedu dalam hati untuk mengangkut kolesterol melalui eksresi feses yang mana proses tersebut membutuhkan HDL darah untuk melakukannya.

\section{SIMPULAN}

Penambahan tepung daun kayamang (Salvinia molesta) sampai taraf $18 \%$ menurunkan bobot hidup secara signifikan, tetapi mampu menurunkan persentase lemak abdominal. Penambahan tepung daun kayambang meningkatkan kandungan LDL dan menurunkan HDL dalam darah.

\section{DAFTAR PUSTAKA}

Agung, M. U. K., K. Haetami dan Y. Mulyani. 2007. Penggunaan Limbah Kiambang Jenis duckweeds dan Azola dalam Pakan dan Implikasinya Pada Ikan Nilem. Fakultas Perikanan dan Ilmu Kelautan. Laporan Penelitian Penelitian Dasar (Litsar) Universitas Padjadjaran, Bandung.

Anggorodi, R. 1985. Kemajuan mutakir dalam Ilmu Makanan Ternak Unggas. Universitas Indonesia, Jakarta.

Amrullah, I. K. 2004. Nutrisi Ayam Broiler. Lembaga Satu Gunungbudi, Bogor.

Basmacioglu, H. and M. Ergul. 2005. Research on the factor affecting cholesterol content and some other characteristics of eggs in laying hens. Turk. J. Vet. Anim . Sci. 29: 157-164.

Chashnidel, F., H. Moravej, A., Towhidi, F., Asadi and S. Zeinodini. 2010. Influence of different levels of n-3 supplemented (fish oil) diet on performance, carcass quality and fat status in broilers. African $\mathrm{J}$ of Biotechnology 9 (5) : 687-691.

Coetzee, G. J. M and L. C. Hoffman. 2002. Effect of various dietary n-3/n-6 fatty acid ratios on the performance and body composition of broilers. South African J. Anim Sci. 32 : 175-184.

Hermier, D. 1997. Lipoprotein metabolism and fattening in poultry. J. Nutr. 127:805S$808 \mathrm{~S}$ 
Muchtadi, D., N.S. Palupi dan M. Astawan. 1993. Metabolisme Zat Gizi. Pustaka Sinar Harapan IPB, Bogor.

Mukherjee, A. K., P. Kalita, B. G. Unni, S. B.Wann, D. Saikia and P. K. Mukhopadhyay. 2010. Fatty acid composition of four potential aquatic weeds and their possible use as fish feed neutraceuticals. Food. Chem. 123: 12521254.

Murray, K. Robert, K. Daryl, A. M. Peter, W. R. Viictor. 2003. Biokimia Harper. Edisi 25. Penerjemah: Andi Hartoko. EGC. Jakarta.

Saleh, H., S. H., K. Rahimi, M. A. Torshizi,. 2009. The effect of diet that contained fish oil on performance, serum parameters, the immune system and the fatty acid composition of meat in broilers. Int.J.Vet.Res. 3 (2) : 69-75

Santosa, U. dan K. Tanaka. 2001. Pengaruh umur terhadap aktivitas enzim lipogenik di hati dan akumulasi lemak pada ayam broiler. JITV. 6 (2) : $89-93$.

Sardesai, V. M. 1992. Nutritional role of polyunsaturated fatty acids. J. Nutr. Biochem 3 : 154-166.

Siri, S., H. Tobioka, I. Tasaki . 1992. Effects of dietary cellulose level on nutrient utilization in chickens. Asian. Aust. Anim. Sci. 5 (4) : 741 - 746.

Sumiati dan A. Sumirat. 2003. Persentase bobot saluran pencernaan dan organ dalam itik lokal (Anas platyrhyncos) jantan yang diberi berbagai taraf kayambang (Salvinia molesta) dalam ransumnya. Med. Pet. 26 (1): 11-16. 